\title{
Effect of seedbed methods and time of harvest on the yield and nutritive value of some forage crops grown on Vertisol at Debre Zeit, Ethiopia
}

\author{
Abate Tedla, Helena Airaksinen and M.A. Mohamed-Saleem \\ Tedla, A., Airaksinen, H. \& Mohamed-Saleem, M.A. 1992. Effect of seedbed \\ methods and time of harvest on the yield and nutritive value of some forage crops \\ grown on Vertisol at Debre Zeit, Ethiopia. Agric. Sci. Finl. 1: 491-497. (International \\ Livestock Centre for Africa (ILCA), P.O. Box 5689, Addis Abeba, Ethiopia.)

\begin{abstract}
The influence of the improved drainage broadbed and furrow (BBF), as opposed to the traditional flat seedbed over the growing season on the dry matter yield and nutritive value of Avena sativa, Vigna unguiculata, Lablab purpureus, Vicia dasycarpa, Trifolium steudneri and Sesbania sesban were studied on Vertisol. Up to 7 tha dry matter yield was recorded for Avena sativa and Lablab purpureus when planted on Vertisols with improved drainage. Dry matter yield of forage crops also increased with advance in stage of maturity or subsequent harvests. On both improved and traditional flat seedbed methods, the chemical analysis of forage crops showed similar declines in crude protein content and in vitro dry matter digestibility (IVDMD) levels as the maturity of forage crops progressed.
\end{abstract}

Key words: Ethiopian highlands, Vertisols, forage legumes, Avena sativa

\section{Introduction}

Integrated crop-livestock production is a long tradition in the Ethiopian highlands (above $1500 \mathrm{~m}$ altitude). Livestock provides draught power for tillage and transport and manure for crops while crop residues serve as important feed resources (GRYSEELS 1988).

Vertisols (deep clay soils) in Ethiopia cover about 12 million ha; 7.6 million ha are found in the highlands. Only about 2 million ha of Vertisols are under cultivation in the highlands. The remainder is not cropped because of waterlogging caused by high rainfall amounts (JUTZI 1986).
The traditional flat seedbed method is generally used on Vertisols by farmers. However, it cannot effectively overcome the problem of waterlogging (BERHANU 1985). Research at the International Livestock Centre for Africa (ILCA) on animal traction showed that the development of an appropriate animal drawn implement (broadbed maker) for seedbed-shaping helped to overcome the problems of waterlogging. The broadbed maker forms the seedbed into broadbeds and furrows (BBF) which provides better drainage for cropping.

On Vertisols and other soils in the highlands, native pasture and crop residue are the major feed resources. However, quality and quantity of these 
feedstuffs are insufficient to meet livestock requirements (LULSEGED and ALEMU 1984). Delayed harvest of native pasture for hay is also responsible for its low nutritive quality (JUTZI et al. 1987).

In order to alleviate these problems, ILCA's Highland Programme has focused its research on the evaluation of forage crops, especially legumes, for the highlands. In earlier studies, Avena sativa, Vigna unguiculata, Lablab purpureus, Vicia dasycarpa, Trifolium steudneri and Sesbania sesban have shown potential for the medium altitude (1500-2400 $\mathrm{m}$ asl) highlands of Ethiopia (Lulseged and Alemu 1984; JutZi et al. 1987). These forage crops can provide high quality feed either as cut and carry during the rainy season or as hay for dry season feed when seasonal feed shortages become a serious impediment to meeting livestock requirements. These forage crops are high yielding (ABATE 1984) compared with native pastures that have annual yields of only 3-4 t/ha (JUTZI et al. 1987) of dry matter, are poor in quality and result in low livestock performance in the dry season.

The role of forage legumes in increasing animal performance is well documented (SHAw 1961, 1978; TothILL 1974). However, the yield and quality of these forage crops are influenced by harvest time and drainage. In this study, field experiments were designed to examine the yield and quality trends of potential forage crops under the traditional and improved seedbed methods on Vertisol at different harvest times during the growing season.

\section{Material and methods}

Field experiments were conducted in the Ethiopian highlands, at ILCA's Debre Zeit Research Station (1800 m asl) from 1989 through 1990. The soil of the experimental site is Vertisol, which would normally present drainage problems in the high rainfall season. Rainfall occurs from mid June to mid September (main rainy season) and from Feb-ruary to April (small rainy season). Average annual rainfall is about $800 \mathrm{~mm}$, with $70 \%$ usually falling in the main rainy season.

In the first year of the study, a randomised complete block design experiment with four replicates in a factorial arrangement of two seedbed methods using three forage legumes giving a total of 6 treatments each in a $3.6 \times 20 \mathrm{~m}$ plot was established.

The flat seedbed represented the traditional system. The broadbed and furrow (BBF) was the improved drainage system intended to allow early planting on Vertisols and the removal of excess water from the seedbed.

In the second year, the experiment was sown as a split plot design. The two seedbed methods were used as main plots (each $18 \mathrm{~m} \times 20 \mathrm{~m}$ ) and he forage crops (one fodder oat and four legumes) were used as sub plots (each $3.6 \mathrm{~m} \times 20 \mathrm{~m}$ plot) with six replicates of each. The forage crops studied and their seed rates are shown in Table 1. At sowing, $100 \mathrm{~kg} / \mathrm{ha}$ di-ammonium phosphate fertiliser was applied uniformly to all treatments in both years.

Sampling was done using a quadrant frame of $1 \mathrm{~m}^{2}$ in each sub plot which was repeated five times to provide yield estimation per net plot of $5 \mathrm{~m}^{2}$ for each forage crop. Harvests were done randomly at 6,12 and 18 weeks after plant emergence in the first year. Harvesting was carried out at 6, 9, 12, 15 and 18 weeks after plant emergence in the second year in order to determine dry matter yield and

Table 1. Forage crops and their seed rate used for the study on Vertisols in the 1989 and 1990 cropping season.

\begin{tabular}{llr}
\hline $\begin{array}{l}\text { Study } \\
\text { year }\end{array}$ & Forage Species & $\begin{array}{r}\text { Seed rate } \\
\mathrm{kg} / \mathrm{ha}\end{array}$ \\
\hline 1989 & Sesbania sesban & 20 \\
& Lablab purpureus & 50 \\
& Vigna unguiculata & 75 \\
1990 & Avena sativa & 100 \\
& Lablab purpureus & 50 \\
& Vigna unguiculata & 75 \\
& Vicia dasycarpa & 25 \\
& Trifolium steudneri & 13 \\
\hline
\end{tabular}


nutritive value over the growing season. The dry matter data were subjected to analysis of variance (SAS); LSD and SED were used for mean comparisons.

\section{Results}

\section{Dry matter yield}

Dry matter yields of the three forage crops in the 1989 crop season at different harvest times over the growing season are shown in Table 2 .

There was no significant difference in dry matter yield between the flat and BBF seedbed methods at 6 weeks after emergence. However, at 12 and 18 weeks after emergence, there were significant differences in dry matter yield $(\mathrm{P}<0.05)$ between the forages grown on the two seedbed methods. Among the forage crops, dry matter yield differences were statistically significant at 6 weeks $(\mathrm{P}<0.001), 12$ weeks $(\mathrm{P}<0.05)$ and 18 weeks $(\mathrm{P}<0.01)$ after plant emergence.

When harvested at 18 weeks, Lablab purpureus had the highest dry matter yield, followed by Vigna unguiculata. However, the performance of Vigna unguiculata at earlier harvests was the highest of the two forage crops.

The seedbed method by forage crop interaction on dry matter yield was significant at harvests of 6 weeks $(\mathrm{P}<0.05)$ and 12 weeks $(\mathrm{P}<0.05)$ after emergence. The interaction effect at 18 weeks after emergence was not significant.

Dry matter yields of the five forage crops in the 1990 cropping season at different harvest times over the growing season are given in Table 3. With the exception of the 18 week harvest time, there were no significant dry matter yield differences between the flat and BBF seedbed methods. There were highly significant differences $(\mathrm{P}<0.001)$ in dry matter yield among the forage crops at all harvest times. The interaction of seedbed method by forage crop was only significant $(\mathrm{P}<0.05)$ at 6 weeks after emergence.

From the forage crops evaluated, Avena sativa had the highest dry matter yield $(7983 \mathrm{~kg} / \mathrm{ha})$ followed by Lablab purpureus $(6292 \mathrm{~kg} / \mathrm{ha})$. The lowest yield was recorded for Vicia dasycarpa at 18 weeks after emergence.

Table 2. The mean dry matter yields (kg/ha) of three forage crops under the traditional seedbed method (FLAT) and on drained (BBF) Vertisol and harvested at different times during the growing season at Debre Zeit, 1989.

\begin{tabular}{|c|c|c|c|c|}
\hline \multirow[t]{2}{*}{ Seedbeds } & \multirow[t]{2}{*}{ Forage crop } & \multicolumn{3}{|c|}{$\begin{array}{c}\text { Time of harves } \\
\text { (week after plant emergence) }\end{array}$} \\
\hline & & 6 & 12 & 18 \\
\hline \multirow[t]{3}{*}{ FLAT } & Sesbania sesban & 250 & 1980 & 2500 \\
\hline & Lablab purpureus & 650 & 4450 & 6410 \\
\hline & Vigna unguiculata & 830 & 4780 & 6010 \\
\hline \multirow[t]{8}{*}{ BBF } & Sesbania sesban & 540 & 2490 & 3650 \\
\hline & Lablab purpureus & 470 & 3360 & 7140 \\
\hline & Vigna unguiculata & 1040 & 4000 & 5930 \\
\hline & LSD $(5 \%)$ & 150 & 1230 & 1320 \\
\hline & F-test probability & & & \\
\hline & Seedbed method (SM) & NS & $\mathrm{P}<0.05$ & $\mathrm{P}<0.05$ \\
\hline & Forage crops (FC) & $\mathrm{P}<0.001$ & $\mathrm{P}<0.05$ & $\mathrm{P}<0.01$ \\
\hline & Interaction $(\mathrm{SM} \times \mathrm{FC})$ & $\mathrm{P}<0.05$ & $\mathrm{P}<0.05$ & NS \\
\hline
\end{tabular}


Table 3. The mean dry matter yield $(\mathrm{kg} / \mathrm{ha})$ of five forage crops under the traditional seedbed method (FLAT) and on drained (BBF) vertisol and harvested at different times of the growing season at Debre Zeit, 1990.

Seedbed method and

Forage Crop

\section{Seedbed method}

FLAT

BBF

SED

\section{Forage Crop}

Avena sativa

Lablab purpureus

Vigna unguiculata

Vicia dasycarpa

Trifolium steudneri

SED

F-test probabilities

Seedbed method

Forage crop

Interaction $(\mathrm{SM} \times \mathrm{FC})$

\section{7}

390

62

6

9

Time of harvest

(week after plant emergence)
15

4325

4443

248

6471

4426

3377

3649

3998

313

33
18

5134

5672

182

7983

6292

4202

3987

4552

518

118

293

NS

$\mathrm{P}<0.001$

NS

$\mathrm{P}<0.001$

NS

$\mathrm{P}<0.001$

NS

$\mathrm{P}<0.001$

NS

$\mathrm{P}<0.05$

$\mathrm{P}<0.001$

NS

Table 4. The mean * values of the forage crop chemical composition (nutritional status) harvested at different times onVertisol at Debre Zeit, 1989.

\begin{tabular}{|c|c|c|c|c|c|c|c|}
\hline $\begin{array}{l}\text { Harvest } \\
\text { time } \\
\text { (week) }\end{array}$ & Forage crop & $\begin{array}{c}\text { Ash }^{1} \\
\%\end{array}$ & $\begin{array}{c}\mathrm{CP}^{2} \\
\%\end{array}$ & $\begin{array}{c}\mathrm{NDF}^{3} \\
\%\end{array}$ & $\begin{array}{c}\mathrm{ADF}^{4} \\
\%\end{array}$ & $\underset{\%}{\text { Lignin }^{5}}$ & $\begin{array}{c}\text { ADF-As } \\
\%\end{array}$ \\
\hline 6 & $\begin{array}{l}\text { Sesbania sesban } \\
\text { Lablab purpureus } \\
\text { Vigna unguiculata }\end{array}$ & $\begin{array}{l}11.2 \\
14.7 \\
22.1\end{array}$ & $\begin{array}{l}20.3 \\
18.2 \\
19.2\end{array}$ & $\begin{array}{l}37.9 \\
36.4 \\
40.5\end{array}$ & $\begin{array}{l}28.0 \\
29.6 \\
29.1\end{array}$ & $\begin{array}{l}4.8 \\
4.7 \\
5.1\end{array}$ & $\begin{array}{l}0.4 \\
2.2 \\
4.4\end{array}$ \\
\hline 12 & $\begin{array}{l}\text { Sesbania sesban } \\
\text { Lablab purpureus } \\
\text { Vigna unguiculata }\end{array}$ & $\begin{array}{r}8.9 \\
13.3 \\
10.4\end{array}$ & $\begin{array}{l}12.6 \\
20.7 \\
11.8\end{array}$ & $\begin{array}{l}45.6 \\
42.5 \\
48.1\end{array}$ & $\begin{array}{l}34.6 \\
35.8 \\
40.3\end{array}$ & $\begin{array}{l}6.1 \\
7.0 \\
6.7\end{array}$ & $\begin{array}{l}0.4 \\
1.9 \\
0.7\end{array}$ \\
\hline 18 & $\begin{array}{l}\text { Sesbania sesban } \\
\text { Lablab purpureus } \\
\text { Vigna unguiculata }\end{array}$ & $\begin{array}{l}7.8 \\
9.0 \\
9.9\end{array}$ & $\begin{array}{l}11.0 \\
12.3 \\
14.7\end{array}$ & $\begin{array}{l}48.5 \\
48.0 \\
45.9\end{array}$ & $\begin{array}{l}37.2 \\
39.4 \\
37.0\end{array}$ & $\begin{array}{l}5.9 \\
6.9 \\
6.7\end{array}$ & $\begin{array}{l}- \\
0.3 \\
0.7\end{array}$ \\
\hline
\end{tabular}

* Average value taken from FlAT and BBF seedbed methods. 1. Ash ( $\%$ of dry matter, DM) 2. Crude protein ( $\%$ DM)

3. Neutral detergent fiber ( $\%$ DM) 4. Acid detergent fiber ( $\%$ DM) 5. Lignin ( $\%$ DM) 6. Acid detergent fibre-Ash ( $\%$ DM). 


\section{Nutritional value of the forage crops}

The chemical analysis of the forage crops for the 1989 season, sampled at different harvest times after plant emergence, is presented in Table 4. The chemical analysis of the forage crops in the 1990 season is shown in Table 5. In general, crude protein content and in vitro dry matter digestibility levels declined as the forage crops matured.

The nutritional value of the forage crops at each harvest, using the flat and BBF seedbed methods, showed no statistically significant differences.
Thus, the values for the various quality parameters are presented as an average of the two seedbed methods.

\section{Discussion}

At Debre Zeit, an overall positive effect of the BBF was observed at the later stage of forage growth for the forage crops tested. This is reflected in the increased dry matter yields of forage crops over the traditional flat seedbed method. However, indi-

Table 5. The mean * values of the forage crop chemical composition (nutritional status) harvested at different times on Vertisol at Debre Zeit, 1990.

\begin{tabular}{|c|c|c|c|c|}
\hline $\begin{array}{l}\text { Harvest } \\
\text { time } \\
\text { (week) }\end{array}$ & Forage crop & $\begin{array}{c}\text { Ash }^{1} \\
\%\end{array}$ & $\begin{array}{c}\mathrm{CP}^{2} \\
\%\end{array}$ & $\begin{array}{r}\text { IVDMD }^{3} \\
\%\end{array}$ \\
\hline \multirow[t]{5}{*}{6} & Avena sativa & 15.3 & 21.9 & 79.9 \\
\hline & Lablab purpureus & 18.4 & 22.9 & 76.4 \\
\hline & Vigna unguiculata & 20.6 & 25.1 & 79.2 \\
\hline & Vicia dasycarpa & 32.3 & 23.7 & 76.1 \\
\hline & Trifolium steudneri & - & - & - \\
\hline \multirow[t]{5}{*}{9} & Avena sativa & 13.8 & 13.5 & 76.0 \\
\hline & Lablab purpureus & 17.4 & 23.8 & 74.1 \\
\hline & Vigna unguiculata & 19.2 & 25.3 & 76.8 \\
\hline & Vicia dasycarpa & 24.0 & 23.4 & 72.1 \\
\hline & Trifolium steudneri & 15.5 & 20.5 & 73.7 \\
\hline \multirow[t]{5}{*}{12} & Avena sativa & 10.8 & 6.8 & 67.9 \\
\hline & Lablab purpureus & 12.2 & 20.4 & 65.9 \\
\hline & Vigna unguiculata & 14.7 & 22.1 & 73.2 \\
\hline & Vicia dasycarpa & 13.4 & 24.0 & 68.3 \\
\hline & Trifolium steudneri & 15.6 & 21.6 & 75.0 \\
\hline \multirow[t]{5}{*}{15} & Avena sativa & 9.8 & 7.3 & 62.5 \\
\hline & Lablab purpureus & 11.5 & 8.7 & 63.2 \\
\hline & Vigna unguiculata & 12.6 & 21.7 & 68.8 \\
\hline & Vicia dasycarpa & 13.0 & 24.1 & 62.7 \\
\hline & Trifolium steudneri & 15.8 & 21.1 & 72.0 \\
\hline \multirow[t]{5}{*}{18} & Avena sativa & 10.8 & 6.6 & 55.3 \\
\hline & Lablad purpureus & 11.0 & 15.4 & 63.3 \\
\hline & Vigna unguiculata & 11.5 & 16.0 & 68.6 \\
\hline & Vicia dasycarpa & 12.3 & 18.7 & 63.7 \\
\hline & Trifolium steudneri & 12.1 & 11.5 & 61.2 \\
\hline
\end{tabular}

* Average value taken from FLAT and BBF Seedbed methods. 1. Ash (\% DM) 2. Crude protein (\% DM) 3. In vitro dry matter digestibility (\% DM). 
vidual forage crop responses to seedbed method differed over the growing season (Table 2). The dry matter yields of Lablab porpureus (harvested at 6 and 12 weeks) and Vigna unguiculata (harvested at 12 and 18 weeks)appeared to be higher on the flat seedbed than on the BBF. In part, this can be attributed to the low rainfall (range $700-800 \mathrm{~mm}$ per annum), the low clay content $(49 \%)$ of the soil (KAMARA and HAQUE 1987) and the relatively high evaporative demands that cause varied drainage problems on different forage growth.

These results are in contrast with those from higher altitudes $(>2400 \mathrm{~m}$ asl $)$ where clay content greater than $60 \%$ is recorded for Vertisols, rainfall exceeds $1000 \mathrm{~mm}$ per annum and temperatures are lower. These effects result in poor drainage on plant growth throughout the growing season (JUTZI 1983). Of the forage crops tested, Avena sativa, Lablab purpureus and Vigna unguiculata produced high dry matter yields ( $>6 \mathrm{t} / \mathrm{ha})$ in both seasons.

The legumes are of particular importance for their high forage quality (Table 4 and 5). Protein content was high at the earliest harvests but declined gradually as the legume matured. This result was ex- pected because older plants are more heavily lignified and normally produce poor quality forage.

\section{Conclusion}

The performance of these forage legumes in terms of yield and quality suggests they are crops of choice for integration into mixed crop - livestock systems in the highlands. However, further studies are needed on how these forages are combined with food crops in land short systems in order to be used for livestock feed.

It is expected that if these forage legumes are successfully introduced into the highland cereal cropping system, they could have a significant impact on livestock production.

Acknowledgements. The authors wish to express their appreciation to the Government of Switzerland (SDC) and Finnish International Development Agency (FINNIDA) for the support of Vertisol work reported here at ILCA.

The extensive assistance also provided by the Vertisol staff involved in this work especially W/o Nigist Wagaye and W/t Etalem Engeda are acknowledged.

\section{References}

AвATE, T. 1984. Results of 1983/84 Forage Network Trials. ILCA Highlands Programme, Addis Abeba, Ethiopia. 15 p.

Berhanu, D. 1985. The Vertisols of Ethiopia: their propeties, classification and management. Fifth meeting of the Eastern African Sub-Committee for Soil Correlation and Land Evaluation. Wad Medani, Sudan. World Soil Resources Reports No. 56. FAO, Rome. p. 31-54.

GRYSEELS, G. 1988. Role of livestock on mixed smallholder farms in Ethiopian highlands. A case study from the Baso and Worena woreda near Debre Berhan. Dissertation, Agric. Univ., Wageningen, The Netherlands. 249 p.

Jutzi, C.S., Haque, I. \& ABATE, T. 1987. The production of Animal feed in the Ethiopian highlands. Potentials and Limitations. In: IAR Proc. national livestock conference, Inst. Agric. Res., Addis Abeba (Ethiopia). 1. National Livestock Improvement Conference, Addis Abeba Ethiopia p. 141-142

- 1983. Forage legumes. Networkshop on draft power and animal feeding, CIMMIT, Mexico city Mexico. Eastern and Southern Africa Economics Programme. CIMMIT Networkshop on Draft Power and Livestock Feeding in Eastern and Southern Africa, Mbabane Swaziland 8 p.

Jutzı, S.C. 1986. Deep black soils (Vertisols) management options for Ethiopian highlands. African Mountains Workshop, Geo-ecology International Geographical Union, Addis Abeba, Ethiopia.

Kamara, C.S. \& Haque, I. 1987. Characteristics of Vertisols at ILCA research and outreach sites in Ethiopia, ILCA PSD Working paper No. B5.

Lulseged, G. \& Alemu, T. 1984. Pasture Research Development in Ethiopia. Pasture Improvement Research in Eastern and Southern Africa. In: Proc. Workshop held in Harare, Zimbabwe.

Sнаw, N.H. 1961. Increased beef production from Townsville lucerne (Stylosanthes sundaicad Tauh) in the spare grass pasture of Central Queensland. Australia J. Agric. Animal Husb. 1: 73-80.

- 1978. Superphosphate and stocking rate effect on native pasture oversown with Stylosanthes humilis in 
Central Coastal Queensland. 2. Animal Production. Australian J. Exp. Agric. Animal Husb. 18: 800-807.

TothILL, J.C. 1974. Experiences in Sod-seedling Siratro into native spear grass pasture on granite soils near Mundubbera. Tropical Grassland. 8: 128-132.
Manuscript received March 1992

Tedla Abate

Helena Airaksinen

M. A. Mohamed-Saleem

International Livestock Centre for Africa (ILCA)

P.O. Box 5689

Addis Abeba, Ethiopia

\title{
SELOSTUS
}

\section{Kylvöalustan muokkaustapojen ja sadonkorjuuaikojen vaikutusten vertailu kasvien satotasoon ja ravintoarvoon Vertisol-savimailla Debre Zeitissa, Etiopiassa}

\author{
Abate Tedla, Helena Airaksinen ja M. A. Mohamed-Saleem \\ International Livestock Centre for Africa (ILCA)
}

\begin{abstract}
Tutkimuksessa verrattiin parannetun pellon muokkauksen (kuivatuksen, leveäă kohotettua kyntöviilua käyttämällă (BBF)) ja perinteisen tasaisen muokkauksen vaikutuksia Avena sativan, Vigna unguinatan, Lablab purpureumin, Vicia dasycarpan, Trifolium steudnerin ja Sesbania sesbanin kuiva-aine satotasoihin ja ravintoarvoihin vertisol-savimailla Debre Zeitissa, Etiopiassa. Tutkimus suoritettiin vuosina 1989 ja 1990. Ensimmäisenä vuonna kăytettiin satunnaistettujen lohkojen muotoista faktorikoketta ( $2 \times 3$ tasoa). Toisena vuonna käytettiin osaruutukoetta, jossa pääruututasolla olivat muokkausmenetelmăt ja osaruututasolla olivat kasvit.

Tarkoituksena oli testata parannetun muokkauksen (BBF) vaikutusta perinteiseen muokkaukseen verrattuna. BBF-
\end{abstract}

muokkausmenetelmă mahdollistaa aikaisemman kylvön, koska liika vesi valuu pois kylvöalustalta, mikä mahdollisesti lisää satotasoa. Koelohkoilla, joilla oli käytetty BBF muokkausta, Avena sativa ja Lablab purpureum tuottivat 7 th kuiva-aine hehtaarisatoja. Myöhäisempi kasvuaste ja korjuuaika lisäsivăt myös kuiva-ainesatoja. Kasvien raakavalkuaispitoisuus ja kuiva-aineen in vitro sulavuus aleinivat kasvuasteen edetessä eikä muokkaustavoilla ollut vaikutusta saatuihin arvoihin.

Selostettu tutkimus tehtiin Afrikan kansainvälisessä kotieläintutkimuskeskuksessa ILCA:ssa, Etiopiassa. Tutkimusta rahoittivat Sveitsin hallitus ja Suomen Ulkoasiainministeriön Kehitysyhteistyöosasto. 